固相抽出ピペットチップによる尿中乱用薬物のマイクロ抽出法の検討

鈴木雄亮, 佐藤雅子, 金子 毅

千葉県警察本部科学捜査研究所

干260-0024 千葉県千葉市中央区中央港 1-71-1

\title{
Micro Solid Phase Extraction ( $\mu$ SPE) of Illicit Drugs in Urine Using Pipette Tip Type Extraction Device
}

\author{
Yusuke Suzuki, Masako Sato and Tsuyoshi Kaneko \\ Forensic Science Laboratory, Chiba Prefectural Police H.Q. \\ 1-71-1, Chuoko, Chuo-ku, Chiba-shi, Chiba 260-0024, Japan
}

(Received 6 April 2007; accepted 1 August 2007)

\begin{abstract}
A microextraction method using a pipette tip type solid phase extraction ( $\mu \mathrm{SPE})$ device was developed for extraction of illicit drugs in human urine. Three types of pipette tips with monolithic SCX, C18 and C4 were compared with recovery of illicit drugs and metabolites such as methamphetamine, amphetamine, 3,4methylendioxymethamphetamine, 3,4-methylendioxy-amphetamine, ketamine and norketamine, respectively.

The recovery was low $(<64 \%)$ with SCX type pipette tip, however, C18 and C4 type tips were suitable to extract these drugs in high recovery $(>86 \%$ and $>81$ $\%$, respectively) from $50 \mu \mathrm{L}$ urine sample. And this extraction procedure was completed in five minutes.

Therefore, this microextraction method using C18 type $\mu$ SPE device was useful for rapid and simple extraction of illicit drugs in small volume urine sample.
\end{abstract}

Key words: Solid phase extraction, Illicit drug, LC/MS

\section{1. はじめに}

現在，尿などの生体試料からの薬毒物の抽出は， 主に有機溶剂を使用した液一液抽出法 ${ }^{1-4)}$ や吸着剂な どを充填したカートリッジによる固相抽出法4-15) に より行われている.

液一液抽出法は，目的物質の特性に合わせた試料 溶液の液性調整や抽出溶媒の違いによって選択的に 目的成分を抽出することが可能であるが，回収の向
上のためには同じ抽出操作を数回繰り返す必要があ る.このことは抽出のために使用する有機溶剂を多 量に使用することになり，環境や経済的な面などか ら多くの問題となっている．さらに抽出溶媒中には 尿などの生体試料由来の夾雑物も多量に溶解するた め，測定機器を污染するばかりでなく，目的物質の 十分な分離分析が困難となることがある.

一方, 固相抽出法は, カートリッジに充填されて 
いる固定相の種類を選択することにより疎水性から 親水性化合物まで広、範囲の物質の抽出に適応可能 であり，固相抽出が精製・濃縮の手段であることか ら生体試料由来の夾雑物の除去もある程度可能であ る.しかしながら，カートリッジへの保持や溶出操 作を行うために専用のバキュームマニホールドを必 要とすることやクリーンアップのための操作が煩雑 である場合がある。また，固定相に保持された目的 物質を完全に回収するために，3-5 mL の溶媒を必 要とする場合もある.

通常，尿などの生体試料中の薬毒物濃度は $\mathrm{ppb}$ レベルまたはそれ以下であることが多く, 液一液抽 出法や固相抽出法で用いる溶媒量は，その薬毒物の 含有量と比較して多量であることから，測定装置に 導入する前に濃縮操作を必要とし，前処理としての 手間と時間を要する.

最近，マイクロピペット用のチップ先端に充填剂 を取り付けたものが市販されている．これは固相の コンディショニングから保持した目的物質の溶出ま での一連の操作をマイクロピペットに装着した状態 のままで行うことが可能であり，溶出に用いる有機 溶媒も極少量で済むことから，液一液抽出法や従来 のカートリッジを用いた固相抽出法と比較して目的 物質の希釈も最小限に抑えることができるという利 点がある.そこで，本研究では，市販のモノリスの C18,C4 抢よび SCX を充填した固相抽出ピペット チップを用いて，日本国内で乱用が多い塩基性薬物 およびその代謝物 6 種について抽出を試み，その有 用性を検討比較した。

\section{2. 実 験}

\section{1. 試料および材料}

メタンフェタミン (MA) 塩酸塩は大日本製薬社 製のヒロポンを，アンフェタミン（AP）硫酸塩抒 よび 3,4-メチレンジオキシアンフェタミン (MDA) 塩酸塩は厚生労働省から供与されたものを，3,4-メ チレンジオキシメタンフェタミン（MDMA）塩酸 塩は科学警察研究所から供与されたものを，ケタミ ン（KET）塩酸塩は Aldrich 社製のものをノルケタ ミン（norKET）塩酸塩は TOCRIS 社製のものをそ れぞれ用いた。
本実験のために用いた薬物添加尿試料は，いずれ の薬物もその濃度が遊離塩基として $2 \mu \mathrm{g} / \mathrm{mL}$ とな るように健常人の尿に添加したものを用いた.

内部標準物質として SIGMA 社製のメトキシフェ ナミン（MEP）塩酸塩を用い，アセトニトリルお よびギ酸はいずれも和光純薬社製の LC/MS グレー ド用のものを用いた。また，その他の試薬はすべて 市販の特級試薬をそのまま使用した。

\section{2. マイクロ固相抽出 (micro solid phase extrac- tion; $\mu \mathrm{SPE})$}

マイクロ固相抽出 $(\mu \mathrm{SPE})$ は, 固相抽出用ピペ ットチップである VARIAN 社製の C18, C4 および $\mathrm{SCX}$ タイプ $100 \mu \mathrm{L}$ 用 OMIX Pipette Tips をマイク ロピペットに取り付けて行った．Fig. 1 に本実験に 使用した固相抽出用ピペットチップを示す.

いずれのタイプの固相抽出チップも, 固定相の充 填された部位にメタノール $100 \mu \mathrm{L}$ を 2 回通した 後, 蒸留水 $100 \mu \mathrm{L}$ を 2 回通して活性化し, その後 の抽出操作に用いた.

\subsubsection{C18および $\mathrm{C} 4$ タイプによる $\mu \mathrm{SPE}$}

抽出の手順はFig. 2 に示すとおりに行った. 固 相抽出ピペットチップをピペットに取り付け，活性 化処理した後, 希釈した薬物添加尿試料 $100 \mu \mathrm{L}$ （薬 物添加尿 $50 \mu \mathrm{L}$ を水または $50 \mathrm{mM}$ ホウ酸緩衝液 （pH 10） $50 \mu \mathrm{L}$ で希釈したもの）が入ったバイアル 中で吸引・吐出操作を 5 回繰り返すことにより, 薬 物を固相抽出ピペットチップに保持した. 次に，蒸

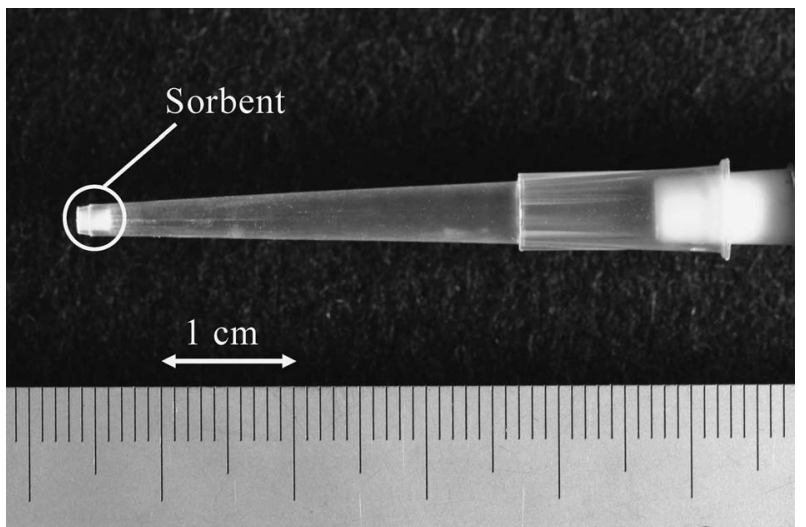

Fig. 1 Micropipette tip type solid phase extraction $(\mu \mathrm{SPE})$ device 


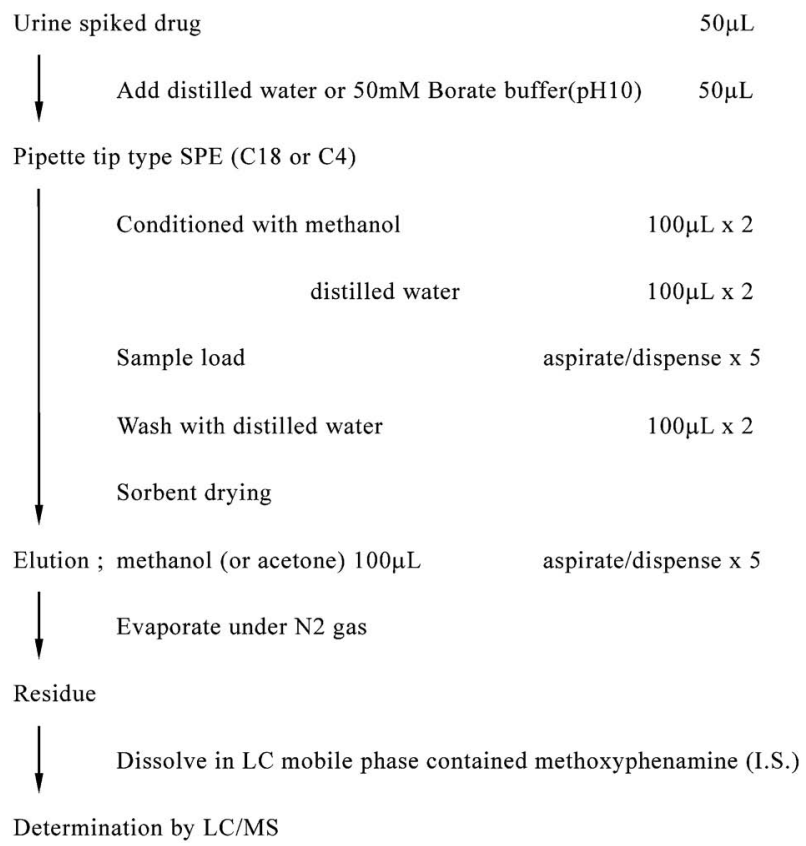

Fig. $2 \mu$ SPE procedure using C18 or C4 type pipette tip

留水 $100 \mu \mathrm{L}$ を 2 回通液することによるクリーンア ップを行った後, 空気の吸引・吐出を数回繰り返し 余分な水分を取り除いた．その後，メタノール100 $\mu \mathrm{L}$ の吸引・吐出を 5 回繰り返し, 薬物の回収を行 った。ここで得られたメタノール溶液は窒素気流下 においてメタノールを留去した後, MEP 濃度が0.2 $\mu \mathrm{g} / \mathrm{mL}$ に調整したギ酸アンモニウム緩衝液（pH 3.5）とアセトニトリルの混合液（10：90）500 $\mu \mathrm{L}$ に溶解し，これをメンブランフィルターでろ過した ものを測定用試料とした。メンブランフィルターは MILLIPORE 社製の Ultrafree-MC $0.22 \mu \mathrm{m}$ Filter Unitを用いた。

\subsubsection{SCX タイプによる $\mu \mathrm{SPE}$}

尿試料の希釈に同等量の水または酸性水溶液を用 い, 固相抽出用ピペットチップヘの薬物の保持は, 前記2.2.1.と同様の手順に従った。洗浄は $10 \mathrm{mM}$ 酢 酸 $100 \mu \mathrm{L}$ で 1 回, メタノール $100 \mu \mathrm{L}$ で 2 回通液す ることによって行い，回収は 5\%アンモニア含有の メタノール $100 \mu \mathrm{L}$ で行った。 その後の試料調製は 2.2.1.と同様の手順により測定用試料を得た.

\section{3. 高速液体クロマトグラフィー質量分析（LC/ MS)}

マイクロ固相抽出により抽出された薬物の測定は LC/MSにより行った。装置は Waters 社製の alliance ZMD を，分離カラムとして phenomenex 社製 の Luna C18(2) $100 \mathrm{~A}(150 \mathrm{~mm} \times 2.0 \mathrm{~mm}$ i.d. $)$ を用 いて行った．溶離液は $10 \mathrm{mM}$ のギ酸アンモニウム 緩衝液 $(\mathrm{pH}$ 3.5) とアセトニトリルの混合液を用い, グラジェント条件はアセトニトリル濃度が $10 \%$ から 20分間で $80 \%$ とした。流速は $0.2 \mathrm{~mL} / \mathrm{min}$ とし，試 料はオートサンプラーを用いて $10 \mu \mathrm{L}$ を注入した。 質量分析の条件は，ポジティブモードのエレクトロ スプレーイオン化法, コーン電圧 $15 \mathrm{~V}$, キャピラ リ一電圧 $3.5 \mathrm{kV}$, ソースブロック温度 $120^{\circ} \mathrm{C}$, 脱溶 媒温度 $350^{\circ} \mathrm{C}$, 脱溶媒ガスとして窒素を $400 \mathrm{~L} / \mathrm{min}$ に設定し，m/z 100から900までのスキャンモード および選択イオンモニタリングモード（m/z 150; MA， 136; AP，194; MDMA，180; MDA および MEP, 238; KET, 224; norKET) により測定を行っ た.

\section{4. ガスクロマトグラフィ一質量分析（GC/MS）}

ガスクロマトグラフィー質量分析は次のと抢りの 条件において行った．装置は島津製作所製のガスク ロマトグラフ質量分析計 GCMS-QP2010を用い, 成分の分離はVARIAN 社製の VF-5 ms キャピラ リーカラム $(30 \mathrm{~m} \times 0.25 \mathrm{mmi} . \mathrm{d} ., 0.25 \mu \mathrm{m})$ により 行った。オーブン温度プログラムは, 初期温度 $50^{\circ} \mathrm{C}$ から昇温速度 $20^{\circ} \mathrm{C} / \mathrm{min}$ で $330^{\circ} \mathrm{C}$ まで昇温し, 最終温 度で 6 分間保持した。注入口温度は $250^{\circ} \mathrm{C}$ に設定 し，キャリアガスとしてへリウムを $47.2 \mathrm{~cm} / \mathrm{sec}$ の 定線速度モードで用いた。質量分析は，イオン化法 として電子衝撃イオン化法を用い， m/ z 40-650の スキャンモードで測定した.

\section{3. 結果および考察}

\subsection{C18および C4 タイプ固相抽出による MA 添 加尿試料からの回収}

薬物（MA）添加尿試料の希釈に，水と小ウ酸緩 衝液（pH 10）を用いた場合に括いてその回収率の 違いを調べたところ，水で希釈したものではC18お よび C4 タイプでいずれも $65 \%$ 程度であったのに対 
し，ホウ酸緩衝液（pH 10）ではいずれも約 $85 \%$ 以 上であった。これは，MAの $\mathrm{pKa}$ がおよそ10であ り，ホウ酸緩衝液（pH 10）で希釈することにより 水で希釈したものよりも遊離塩基状態の MA の存 在比率が増大し, これがイオン化状態の MAより も固相に対する保持率が向上するためと考えられ る.

次に保持した薬物の回収のための溶出溶媒に, メ タノール，アセトン，イソプロピルアルコール，ア セトニトリル，酢酸エチル，ジクロロメタンを用 い，溶出時における各溶媒の吸入 · 吐出回数を 5 回 または10回行った場合の MA の回収率を比較し た。メタノールおよびアセトンでは，5回の吸入 . 吐出操作で保持した MAをほぼ完全に回収でき た。これに対し，5回の吸入・吐出操作におけるイ ソプロピルアルコールでは保持した MA の約 80 \%，アセトニトリルでは約 $70 \%$ ，酢酸エチルでは約 30\%，ジクロロメタンでは約20\%であったため，吸 入・吐出操作を10回にしたところいずれの溶媒にお いても一割程度の改善がみられたが，保持した MA を完全に回収するには至らなかった。また，MAを 効率よく溶出することができたメタノールおよびア セトンについて, 吸入・吐出操作の回数を 1 から 3 回の間で検討したところ，いずれも 2 回の操作で保 持した MA はほぼ完全に溶出していることがわか った.

\subsection{SCX タイプ固相抽出による MA 添加尿試料 からの回収}

薬物（MA）添加尿試料の希釈に，水， $50 \mathrm{mM}$ リン酸緩衝液（pH 3 抢よび $\mathrm{pH}$ 6)，10 mM および $100 \mathrm{mM}$ 酢酸を用いた場合においてその回収率を比 較したところ，62-64\%となり，回収率に顕著な変 化はみられなかった。ここで薬物添加尿試料のかわ りに同濃度の MA 水溶液を用いて同様の方法で抽 出したものについて測定を行ったところ，わずかに 回収率が向上したが MA を全て回収することはで きなかった。このことから，SCX タイプでの回収 率の低さは，MA が固相に保持されず素通りしてい ることと，尿中の成分が薬物の保持を妨害している ことに起因しているものと考えられる.

\section{3. 薬物 (AP, MDMA, MDA, KET, norKET) 添加尿試料からの抽出}

各薬物（AP，MDMA，MDA，KET または nor$\mathrm{KET}$ ）添加尿試料について固相に C18 なたは C4 タ イプを，希釈に $50 \mathrm{mM}$ のホウ酸緩衝液（ $\mathrm{pH} \mathrm{10）を}$ それぞれ使用した $\mu \mathrm{SPE}$ を行ったところ，いずれも $81 \%$ 以上の回収率となった. 回収のための溶出溶媒 には，MAを効率よく溶出することができたメタ ノールまたはアセトンを使用した。これらの溶媒で の回収率の比較を MAの結果もあわせて Table 1 に示す。をた，いずれの薬物においても0.5-5 $\mu \mathrm{g} /$ $\mathrm{mL}$ の濃度の範囲で良好な直線性が得られた（ $\mathrm{r}^{2}>$ $0.999)$.

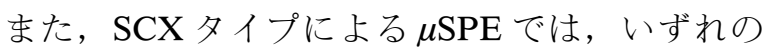
薬物についても50-60\%の回収率であった。これは MA の場合と同様に固相に保持されず素通りしてい ることと，尿中の成分が薬物の保持を妨害している ことに起因しているものと考えられる。

\section{4. 実資料への応用}

酵素免疫測定法によるスクリーニング試験で乱用

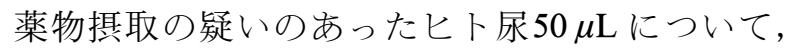

Table 1 Recovery of drugs and metabolites from urine by $\mu \mathrm{SPE}$ (C18 and $\mathrm{C} 4)$.

\begin{tabular}{llll}
\hline \multirow{2}{*}{ Analytes } & \multirow{2}{*}{ Sorbent type } & \multicolumn{2}{c}{ Recovery $(\%)$} \\
& & Methanol & Acetone \\
\hline \multirow{2}{*}{ MA } & C18 & $88.5(3.5)$ & $89.6(1.8)$ \\
& C4 & $85.9(2.0)$ & $86.1(4.6)$ \\
\hline \multirow{2}{*}{ AP } & C18 & $88.5(4.3)$ & $87.6(3.2)$ \\
& C4 & $85.1(1.8)$ & $84.3(1.7)$ \\
\hline \multirow{2}{*}{ MDMA } & C18 & $88.0(1.0)$ & $87.8(3.3)$ \\
& C4 & $85.1(5.3)$ & $81.9(3.5)$ \\
\hline \multirow{2}{*}{ MDMA } & C18 & $90.0(4.4)$ & $90.6(2.8)$ \\
& C4 & $87.8(5.4)$ & $82.2(1.3)$ \\
\hline \multirow{2}{*}{ KET } & $\mathrm{C} 18$ & $86.4(0.8)$ & $90.0(2.9)$ \\
& $\mathrm{C} 4$ & $81.4(1.5)$ & $81.8(3.8)$ \\
\hline \multirow{2}{*}{ norKET } & $\mathrm{C} 18$ & $91.1(2.7)$ & $87.7(1.1)$ \\
& $\mathrm{C} 4$ & $84.7(2.2)$ & $80.8(2.2)$ \\
\hline
\end{tabular}

Human urine were spiked with 6 drugs at a concentration of $2 \mu \mathrm{g} / \mathrm{mL}$, respectively. The values (\%) represent the mean and (C.V.) of four determinations. 
C18タイプの固相抽出用ピペットチップを用いて $\mu \mathrm{SPE}$ を行い，得られた抽出物をトリフルオロアセ チル（TFA）誘導体化した後，ガスクロマトグラ フィー質量分析（GC/MS）を実施したところ, MDMA-TFA 体, MDA-TFA 体, KET-TFA 体抢よ び norKET-TFA 体が検出された。 尿抽出物から得 られたトータルイオンクロマトグラムを Fig. 3 の A に示す.

また，MA 濃度を尿中覚せい鼡鑑定のスクリーニ ングに抢けるカットオフ濃度（遊離塩基として0.5 $\mu \mathrm{g} / \mathrm{mL})$ となるように調製した尿50 $\mu \mathrm{L}$ について， 上記と同様の操作を行い, GC/MS を実施したとこ ろ，MA-TFA 体のピークを確認することができ (Fig. 3, B), 実際の鑑定業務への有用性が示唆され た。

\section{4. 結 論}

マイクロピペット用チップ型固相抽出による尿中

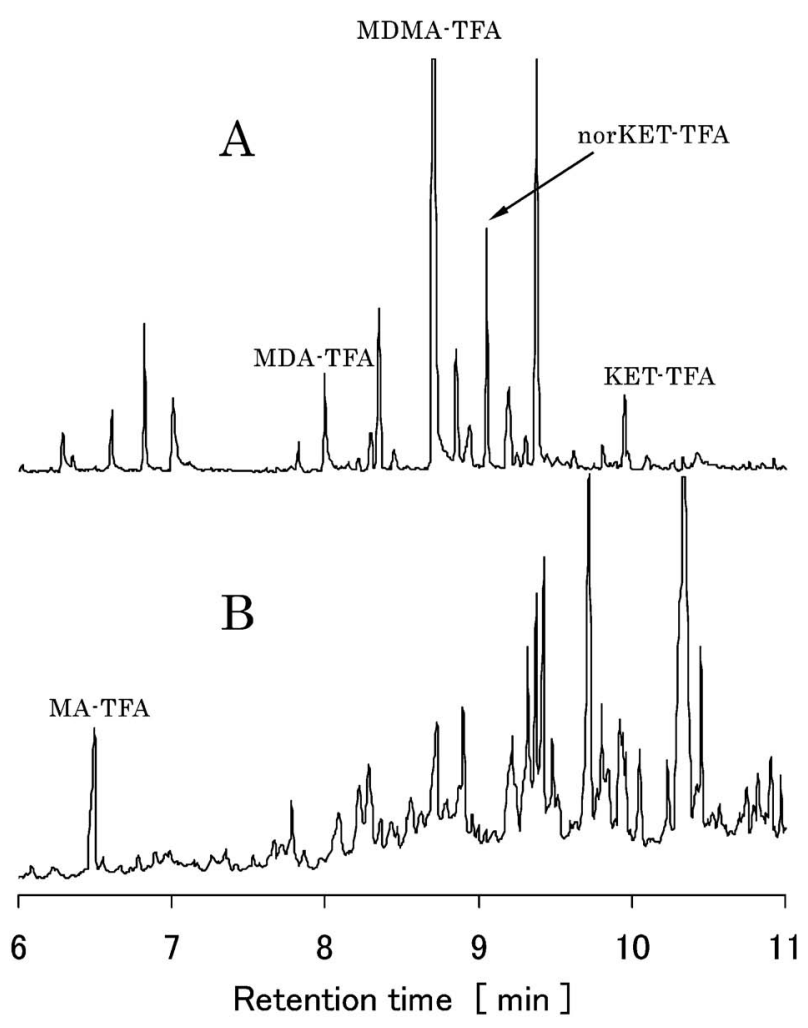

Fig. 3 Total ion chromatograms of extracted drugs (A; MDMA and KET, B; MA) from human urine by $\mu \mathrm{SPE}$ technique.
乱用薬物（MA，AP，MDMA，MDA，KET および norKET）の $\mu \mathrm{SPE}$ は，C4 タイプを用いることによ り $81 \%$ 以上，C18タイプを用いることにより $86 \%$ 以 上の回収率が認められた。

本法は, 現在広く用いられている液一液抽出法や 固相カートリッジによる固相抽出法と比較して, 極 少量 $(50 \mu \mathrm{L})$ の試料から効率よく，1検体あたり 5 分程度という短時間のうちに抽出操作を完了するこ とが可能であるという点で優れており，限られた試 料量から迅速的な結果が求められる法薬毒物分野に おける前処理方法として有用であると考えられる.

\section{参考文献}

1) Widdop, B.: Clarke's Isolation and Identification of Drugs, in pharmaceuticals, body fluids, and post-mortem material, 2nd ed., pp. 10-13, The Pharmaceutical Press, London (1986).

2) Muller, R. K.: Toxicological Analysis, pp. 8390, ULLSTEIN MOSBY, Berlin (1992).

3) Liu, R. H. and Gadzala, D. E.: Handbook of Drug Analysis, Applications in Forensic and Clinical Laboratories. pp. 42-45, American Chemical Society, Washington DC (1997).

4) Huang, Z. and Zhang, S.: Confirmation of amphetamine, methamphetamine, MDA and MDMA in urine samples using disk solid-phase extraction and gas chromatography-mass spectrometry after immunoassay screening. J. Chromatogr. B, 792, 241-247 (2003).

5) Lai, C.-K., Lee, T., Au, K.-M. and Chan, A. Y.-W.: Uniform solid-phase extraction procedure for toxicological drug screening in serum and $\mathrm{u}-$ rine by HPLC with photodiode-array detection. Clin. Chem., 43, 312-325 (1997).

6) Weigel, S., Kallenborn, R. and Hühnerfuss, H.: Simultaneous solid-phase extraction of acidic, neutral and basic pharmaceuticals from aqueous samples at ambient (neutral) $\mathrm{pH}$ and their determination by gas chromatography-mass spectrometry. J. Chromatogr. A, 1023, 183-195 (2004).

7) Boatto, G., Nieddu, M., Carta, A., Pau, A., 
Palomba, M., Asproni, B. and Cerri, R.: Determination of amphetamine-derived designer drugs in human urine by SPE extraction and capillary electrophoresis with mass spectrometry detection. J. Chromatogr. B, 814, 93-98 (2005) .

8) Schütz, H., Gotta, J. C., Erdmann, F., Riße, M. and Weiler, G.: Simultaneous screening and detection of drugs in small blood samples and blood stains. Forensic Sci. Int., 126, 191-196 (2002).

9) Wood, M., Laloup, M., Fernandez, M. del M. R., Jenkins, K. M., Young, M. S., Ramaekers, J. G., De Boech, G. and Samyn, N.: Quantitative analysis of multiple illicit drugs in preserved oral fluid by solid-phase extraction and liquid chromatography-tandem mass spectrometry. Forensic Sci. Int., 150, 227-238 (2005).

10) Molins-Legua, C. and Campins-Falcó, P.: Solid phase extraction of amines. Anal. Chim. Acta, 546, 206-220 (2005).

11) Fuh, M.-R., Wu, T.-Y. and Lin, T.-Y.: Determination of amphetamine and methamphetamine in urine by solid phase extraction and ion-pair liquid chromatography-electrospray-tandem mass spectrometry. Talanta, 68, 987-991 (2006).

12) Bogusz, M. J., Maier, R.-D., Schiwy-Bocdhat, K.-H. and Kohls, U.: Applicability of various brands of mixed-phase extraction columns for opiate extraction from blood and serum. J. Chromatogr. B Biomed. Appl., 683, 178-188 (1996).

13) De Giovanni, N. and Strano Rossi, S.: Simultaneous detection of cocaine and heroin metabolites in urine by solid-phase extraction and gas chromatography-mass spectrometry. J. Chromatogr. B Biomed. Appl., 658, 69-73 (1994).

14) Shou, W. Z., Pelzer, M, Addison, T., Jiang, X. and Naidong, W.: An automatic 96-well solid phase extraction and liquid chromatography-tandem mass spectrometry method for the analysis of morphine, morphene-3-glucuronide and morphine-6-glucuronide in human plasma. J. Pharm. Biomed. Anal., 27, 143-152 (2002).

15) Cognard, E., Bouchonnet, S. and Staub, C.: Validation of a gas chromatography-Ion trap tandem mass spectrometry for simultaneous analyse of cocaine and its metabolites in saliva. J. Pharm. Biomed. Anal., 41, 925-934 (2006). 